\title{
Restricting Free Speech: The Impact on Opposition Parties in Singapore
}

\author{
JAMES GOMEZ
}

\begin{abstract}
Although there has been a great deal of publicity surrounding the restriction of free speech with regard to opposition parties in Singapore, in real terms, the value of free speech for such parties is limited. First, defamation laws in Singapore require the opposition parties to exercise extreme caution to ensure political comments do not result in costly defamation suits or even imprisonment. Second, free speech in itself is of limited use politically for opposition parties if the content of this speech is not disseminated widely by the local media. As a result, both the fear of legal suits and the limited dissemination of content continue to restrict the potential of free speech for opposition parties in Singapore. This means the contribution of free speech activities to inter-party debate is low in Singapore, thereby undermining the fundamental role of democracy premised on fair inter-party competition.
\end{abstract}

Keywords: Singapore; Politics, Opposition Parties; Free Speech.

\section{Introduction}

There are more than 20 registered opposition political parties in Singapore and a handful have consistently secured more than a quarter of the votes in the Singapore general elections since 1984 (Mutalib 2003). Some commentators believe that the opposition is also important in exercising a crucial 'checks and balances' role, theoretically curbing any authoritarian excesses that the ruling party might be tempted to introduce (The Sraits Times [hereafter ST], 29 November 1990). Although the opposition's role is described as weak in Singapore, its continued presence to some extent serves to 'legitimize' Singaporean democracy.

However, very little academic work has been produced on opposition parties in Singapore. The most significant body of work has focused on a review of general elections (Josey 1972; Mutalib 1992, 1993; Singh 1992; Rodan 1996; Da Cunha 1997). Other analyses of general elections that discuss opposition parties have been presented as year-in-review studies (Lee 1985; Lew 1989; Vasil 1993; Koh and Ooi 2002). Another 
body of work that incorporates a discussion of opposition parties focuses on the rules and regulations that govern the elections, in particular the history of constitutional amendments (Tremewan 1994; Thio 1997; Ooi 1998; Lam and Tan 1999; Tan 1999; Yeo 2002). To date, only one book exclusively devoted to opposition parties in Singapore has been published (Mutalib 2003), and this is still largely an analysis of various general elections and constitutional amendments.

Although these writings are important and offer information about the challenges of the electoral process and constitutional matters, they do not present us with a full picture of the nature and performance of opposition parties in Singapore. An approach that examines other aspects of opposition parties, in addition to looking at election results, is needed to broaden our understanding of inter-party competition in Singapore.

In the period before the People's Action Party (PAP) came to power, there was a freer political environment which was more conducive to the free-speech activities commonly associated with multi-party democracies (Chia 2005). For the purposes of this paper, free-speech activities can be defined as those attempts by opposition parties to directly communicate with voters and citizens.

The Singapore Constitution provides for free speech, but with restrictions. Clause (1)(a) of Article 14, declares that citizens of Singapore have the 'right to freedom of speech and expression': However, this right is subject to Clause (2) which states that Parliament may by law impose:

(a) on the rights conferred by clause (1) (a), such restrictions as it considers necessary or expedient in the interest of the security of Singapore or any part thereof, friendly relations with other countries, public order or morality and restrictions designed to protect the privileges of Parliament or to provide against contempt of court defamation or incitement to any violence. (Constitution of the Republic of Singapore)

Singapore is unique in the sense that its Constitution's Article 14 on rights begins by focusing on restrictions of freedom of expression - the right of freedom of expression is itself relegated to a secondary role. Therefore, in Singapore, the right to freedom of expression is not absolute, but can be curtailed by Parliament, which has the power to legislate restrictions on these freedoms. Therefore Parliament, and not the courts, dictates the extent of the freedoms guaranteed by the Constitution (Hickling 1992: 186).

Since 1959, the Singapore Parliament has been dominated by one political party - the PAP. Hence, in some ways, the PAP through its control 
of Parliament dictates the extent of freedoms in Singapore, including the rules of inter-party competition. In fact, the rules of the game were changed to ensure the dominance of the PAP. Opposition parties currently operate in a restricted communications environment. The situation is one where electoral rules are constantly revised and tightened, political party fundraising is only allowed under strict conditions, constitutional innovations are undertaken to reduce the growth of opposition parties, the national trade union movement is affiliated with the ruling party, grassroots organizations are politically supervised, and the media is either directly controlled, intimidated, or practices self-censorship. This has led Freedom House to claim that Singaporeans 'cannot change their government democratically' (Freedom House 2005: 562).

In such a restricted environment, one method open to opposition parties is the use of direct verbal communication to get their message across to both small and large groups of people. However, the existence of several key pieces of legislation, which have been revised over the years, does have an impact on opposition parties' effective use of direct verbal communication. It is important to understand that such rules apply equally to all political parties, but in reality the opposition parties are most disadvantaged by these rules. Often there are exceptions for the ruling party in government; alternatively the ruling party uses all the communication tools at its disposal to control speech; this is an advantage that opposition parties do not enjoy.

When it comes to direct political communication, opposition parties have been denied permits to hold public events or to make political speeches; they have been charged with defamation of PAP officials both during and outside of election periods; moreover they often risk arrest. Even when they are elected to parliament, their speaking time is limited and their speech is not protected. We shall see later in the paper, on two separate occasions, how opposition politicians were disciplined through the Committee of Privileges. This paper has chosen to focus on the impact that three key pieces of legislation - the Public Entertainments and Meetings Act (2000), the Defamation Act $(1957,1997)$, and parliamentary privileges found in the Parliaments (Privileges, Immunities and Powers) Act $(1962,2000)$ - have had on opposition party communication. These are the laws that have been most frequently used to restrict the freedom of opposition parties' direct verbal communications.

Even though the free speech of opposition politicians is curtailed, such restrictions in themselves are not all that important. It is rather the impact on the content of free speech (tempered by the fear of defamation 
suits), and the non-reportage or misrepresentation of opposition parties' free speech content, especially by the local media, that remain the more important issues. The barriers to the free dissemination of the content of political speech through the local mass media remain an important communications setback for opposition parties. Although the laws under examination in this paper have been revised, this paper will show that nothing really has changed to substantially improve this situation. The reality of these restrictions and incidents convey the message to all citizens, and not just opposition politicians, that it is very difficult to challenge or change the laws set down by the ruling PAP government and that the ruling party is not above using the laws to suppress oppositional voices. The PAP does not acknowledge that free speech and freedom of expression are basic human rights, instead it promotes them as a privilege allowed only to the ruling party. In such a political climate, how do the existing laws affect the free speech activities of opposition parties? If the free-speech environment is so restricted and opposition parties are unable to change the current laws, what options are available for opposition parties?

This paper pulls together the different strands of legislation and history of the free-speech repression of opposition parties, scattered across a variety of works, into a single and coherent focus. Apart from a preliminary analysis, the paper aims to provide a useful empirical reference point for future writings on Singapore politics by introducing free speech as a specific subtheme of research. In doing so, the paper seeks to add to the small but growing number of studies on opposition parties in Singapore and to contribute to a more textured understanding of the extant political environment.

\section{The Public Entertainments and Meetings Act (PEMA) and Free Speech}

The Public Entertainments and Meetings Act (PEMA) of 2000 is the most important legislation affecting free speech in Singapore ${ }^{1}$. The Act has its origins in an Ordinance dating back to 1958, with direct consequences for political parties, especially those of the opposition. The current Act has been the result of several changes and amendments, but its key provisions have remained the same and restrict organized outdoor political communication activities by opposition parties. The Act governs the conduct of public events and meetings, requiring groups or organizations to apply to the police for a permit in order to 
hold gatherings that are open to the public. In other words, the police must sanction all public gatherings in Singapore (South China Morning Post, 10 November 2002).

The Public Entertainment Licensing Unit (PELU) is the government department, and part of the police force, tasked with administering the PEMA. Opposition parties have frequently complained about PELU and its licence approval process. Amongst their main complaints are: PELU's lack of transparency and the way it enforces the Act to 'violate the right to freedom of speech, assembly and association guaranteed by the Constitution' (ST, 18 November 2000); plus the lengthy and bureaucratic process necessary to obtain a licence (which can take up to three or four weeks, and several more to appeal against a rejection). Rejections have also been inconsistent, argued opposition MP Chiam See Tong from the Singapore Progressive Party (SPP) in Parliament in 2000, where he raised the issue of his being denied the opportunity to speak during party-organized dinners in his ward. He noted that in the past, he had been able to obtain permits to speak in public at events run by his town council or his former party the Singapore Democratic Party (SDP) (ST, 18 November 2000). One writer had this to say about the public entertainment laws in Singapore:

The PAP continued to use the threat of 'mischief' to prevent political parties from holding rallies outside elections into the next millennium, making the Singapore Constitution's guarantee of freedom of assembly a provision honoured more in the breach than in the observance. Of course, the restrictions applied to the PAP as well as to the opposition parties - but again, the PAP hardly needed to hold rallies. It held power. (Lydgate 2003: 105)

According to the law, opposition party MPs need to apply for licences each and every time they speak in public, even in their own wards, whereas MPs from the ruling PAP do not have this obligation. The Singapore police force explains the law as follows: 'All speeches require a public-entertainment licence, even when given by an MP in a community event. However, the Act exempts public entertainment provided by or under the auspices of the Government.' For example, PAP MPs do not require a permit when they are speaking in their capacity as advisors to the People's Association grassroots organization at organized events (ST, 18 November 2000).

This inconsistency in the application of the Act was illustrated when the Workers' Party was fined S\$800 in 1986 after a constituency dinner and auction held as part of the Lunar Seventh Month celebrations, at 
which the WP's then chief J. B. Jeyaretnam made a speech unrelated to the festivities. The PELU decreed that because his speech 'had nothing to do with the festivities, and was delivered in public, it needed a separate licence from the dinner itself', and should be considered a separate entertainment item (ST, 18 November 2000).

When opposition MPs do apply for a permit to speak at constituency functions, the applications are often rejected. Chiam See Tong of the Singapore Progressive Party (SPP) has also been refused permission to speak at dinners held by his party in his ward. For example, in 1999 he was denied a licence to make his prepared speech, and was only allowed to make a ten-minute thank-you speech. He handed out copies of his intended speech to the attendees (The West Australian, 22 November 1999). He raised this issue in parliament twice in 2000, and was told by the Home Affairs Ministry that 'political meetings, with political speeches, are never permitted outdoors, because the speeches could turn inflammatory and lead to law-and-order problems' (ST, 18 November 2000). This, however, was not always the case. In 1961, David Marshall, the elected Workers' Party Assemblyman of Anson, staged open rallies which he dubbed 'Report to the People' in his constituency to report to his constituents on parliamentary proceedings (Chan 2001: 254-55). But since then things have changed.

For the last several decades, the PAP has been able use this legislation to deny opposition parties the opportunity for direct, large-scale communication. Such restrictions affect both elected and non-elected opposition politicians. Over the years, opposition politicians have experienced a number of difficulties associated with the entertainment licence. Table 1 shows how opposition party figures have been penalized under the Public Entertainments Act. Opposition leaders first ran foul of the Act for simply breaching it, but thereafter the law was infringed deliberately, especially through the civil disobedience acts of Chee Soon Juan of the SDP. Opposition leaders' arguments in court that their political speeches and meetings did not constitute 'entertainment' led to amendments to the Act in 2000, and to its renaming as the Public Entertainments and Meetings Act (PEMA) with heavier fines. Table 2 illustrates the denial of permits to opposition leaders. Permits are required for events like outdoor political events, but they are seldom or never issued to opposition parties. The denial of permits has applied to three types of outdoor political events organized by the opposition - non-election rallies, dinners with political themes, and marches. 
TABLE 1: Infringements of the PEMA by Opposition Parties

\begin{tabular}{|c|c|c|c|c|}
\hline Name & Party & $\begin{array}{l}\text { Date of } \\
\text { offence }\end{array}$ & Activity & Sanction \\
\hline J. B. Jeyaretnam & WP & 1986 & $\begin{array}{l}\text { Lunar Seventh Month } \\
\text { dinner in own ward }\end{array}$ & Fine of $S \$ 800$ \\
\hline J. B. Jeyaretnam & WP & $\begin{array}{l}30 \\
\text { May } 1987\end{array}$ & $\begin{array}{l}\text { Civil disobedience } \\
\text { protest against arrests } \\
\text { of } 22 \text { professionals } \\
\text { accused of a 'Marxist } \\
\text { conspiracy' against the } \\
\text { government } \\
\end{array}$ & $\begin{array}{l}\text { Charged with attempting to hold an assembly with- } \\
\text { out a police permit and obstructing the police. }\end{array}$ \\
\hline Chee Soon Juan & SDP & $\begin{array}{l}29 \\
\text { December } \\
1998\end{array}$ & $\begin{array}{l}\text { Speech in open space } \\
\text { (Raffles Place) }\end{array}$ & Fine of $S \$ 1,400$ \\
\hline $\begin{array}{l}\text { Chee Soon Juan } \\
\text { and } \\
\text { Wong Hong Toy }\end{array}$ & SDP & $\begin{array}{l}5 \\
\text { January } \\
1999\end{array}$ & $\begin{array}{l}\text { Speech in open space } \\
\text { (Raffles Place) }\end{array}$ & $\begin{array}{l}12 \text { days' jail for both men after refusal to pay fines } \\
\text { amounting to } S \$ 2,500 \text { for Chee and } S \$ 2,400 \text { for } \\
\text { Wong. The amount of the fines was later retroac- } \\
\text { tively reduced to } S \$ 1,900 \text { each to enable both men } \\
\text { to run for the next parliamentary elections. }\end{array}$ \\
\hline Chee Soon Juan & SDP & $\begin{array}{l}15 \\
\text { February } \\
2002\end{array}$ & $\begin{array}{l}\text { Speech at Speakers' } \\
\text { Corner }\end{array}$ & $\begin{array}{l}\text { Fine of } \$ \$ 3,000 \text { and barred from contesting in } \\
\text { elections for the next five years from the time of } \\
\text { conviction. }\end{array}$ \\
\hline $\begin{array}{l}\text { Chee Soon Juan } \\
\text { and } \\
\text { Gandhi } \\
\text { Ambalam }\end{array}$ & SDP & $\begin{array}{l}1 \\
\text { May } \\
2002\end{array}$ & $\begin{array}{l}\text { May Day rally in front } \\
\text { of presidential palace }\end{array}$ & $\begin{array}{l}\text { Jail for } 5 \text { weeks for Chee after he refused pay } \\
\text { fines of } S \$ 4,500 \text {, and disqualified from contesting } \\
\text { in elections for the next five years from the time } \\
\text { of conviction. Ambalam spend one night in jail } \\
\text { and was released after he paid the fine of } S \$ 3,000 \\
\text { the next day. }\end{array}$ \\
\hline
\end{tabular}

Sources: Agence France Presse (2002) 'Dr Chee Challenges Police to Charge Him over Speech', 4 March; Agence France Presse (2002) 'Opposition Rally No Threat to Law and Order': defence lawyer, 1 October; Lloyd-Smith, Jake (2002) 'Singapore Activist Defiant after Jail Term', 10 November; Lydgate, Chris (2003) Lee's Law: How Singapore Crushes Dissent, Scribe Publications, Australia; South China Morning Post (1999) 'Chee Heads to Jail for Unauthorised Public Speech', 2 February; Reuters (1999) 'Chee Released from Jail, Will Fight On', 6 March; Reuters (1999) 'Chee's Fine Reduced, Can Now Run for Office', 25 May; Reuters (2002) 'Fined Politician Loses Chance to Stand in Poll', 30 July.

Changes and amendments to the Act came about when a series of civil disobedience activities were undertaken by the Singapore Democratic Party secretary-general Chee Soon Juan to highlight the unconstitutional nature of the Public Entertainments Act. Two of these acts took place at Raffles Place. The first one was on 29 December 1998, when Chee was duly charged with giving a talk without a licence. J. B. Jeyaretnam, who represented Chee in court for the 29 December 1998 incident, wrote to the president in January 1999, arguing that Chee's talk was not public entertainment in the popular meaning of the word 'entertainment'. He also asserted that the Act 'violated Dr Chee's rights as a citizen, as well as the constitutional right of every citizen of Singapore to freedom of information and assembly', and he further argued it was a very appropriate case to be referred to a constitutional tribunal (ST, 30 January 1999). 
Nonetheless, his arguments were not accepted, and Chee stood trial in court. There, he said his constitutional right to free speech was 'violated by the requirement for public speaking permits', and Jeyaretnam told the court that Chee's offence 'fell outside the scope of the Act and constitutional violation voided the charge'. The judge however said he was 'powerless' to deal with the issue because he did not have the 'power of judicial review' when it came to constitutional matters (Reuters, 1 February 1999). The judge subsequently rejected Chee's argument that the law was unconstitutional, and Chee opted to spend seven days in jail rather than pay the fine of $\$ \$ 1,400$ (South China Morning Post, 2 February 1999).

In March, Chee was put on trial for again violating the Act by making a speech on 5 January 1999, again at Raffles Place (Chee Soon Juan, 5 January 1999). He was found guilty of breaking the public speaking laws and was fined $\$ \$ 2,500$. Again he refused to pay the fine and opted for 12 days' jail instead. In addition, SDP official Wong Hong Toy was found guilty of assisting Chee and was fined $\$ \$ 2,400$. Both appealed against the convictions and made a request for a British Queen's Counsel, a senior lawyer, to argue their cases before Singapore's High Court (Reuters, 6 March 1999). These cases made international news and became the advocacy focus for many international free speech organizations.

Chee had more run-ins with the authorities after he publicly stated that police had refused him permission to hold two public rallies in late 1999. He accused them of 'discrimination and violating the right to free speech after refusing his application to hold rallies' in August. According to the head of the police licensing division in a letter to Chee, the application was rejected because the venues were outdoors and there was 'a potential for trouble' and public 'inconvenience'. In a letter to the Home Affairs Ministry, Chee said officials and MPs from the ruling PAP 'routinely give political speeches in outdoor areas', and asked 'Why should the law not treat all parties equally?' (Agence France Presse, 5 August 1999).

As a result of these highly publicized disputes and civil disobedience acts against the licensing regime, a government concession to free speech was made when it established a Speakers' Corner in September 2000 (Reuters, 28 February 2001). This came about because The Roundtable, a political discussion group, suggested through a series of exchanges in the press the setting-up of free-speech venues. Although then-prime minister Goh Chok Tong was initially not ready for this development because he was worried about managing unbridled free 
speech in such a venue, it was eventually set up (Financial Times, 27 March 1999). However this venue is governed by strict rules: Speakers must register to get prior approval at the police station next to the park, and their speeches are recorded by the government and kept for six years. In addition, speeches may be subsequently used in defamation and criminal proceedings in courts of law. Other restrictions include the banning of certain topics dealing with matters such as race and religion (see Gomez 2002).

Shortly after the Speakers' Corner was introduced, the Public Entertainments Act of 1973 was amended to include the term 'meetings' and become the Public Entertainments and Meetings Act (PEMA) in late 2000 (ST, 14 November 2000). The fines for holding public talks or delivering political speeches without a police permit were doubled from S\$5,000 to S\$10,000. Singapore People's Party (SPP) Secretary-General Chiam See Tong stated that 'As far as the law is concerned, it is against the opposition and nothing has changed'. Opposition MPs said the new law remained restrictive, in that it allowed them to hold public events in their constituencies without a permit but not to give speeches (Reuters, 28 February 2001). No change regarding this issue has since been officially announced, but opposition MPs can speak outdoors at a constituency event provided it is organized by the Town Council ${ }^{2}$ but not by the MPs' political party. ${ }^{3}$ Further, at political events organized by political parties, such as anniversaries of political parties, the only type of speeches allowed are those kept succinct and limited to seasonal greetings and best wishes. ${ }^{4}$

In March 2001, a number of individuals from the Think Centre ${ }^{5}$ applied to hold a rally in a stadium, in support of J. B. Jeyaretnam, who was in danger of becoming bankrupt and losing his seat in Parliament. The application for the permit was rejected by the police on the grounds of potential law-and-order problems, including the stipulation that the Think Centre would be required to raise its own 'significant resources to manage the crowd' (Think Centre, 26 March 2001). A subsequent appeal to the Ministry of Home Affairs was also rejected, again citing 'law-and-order problems' and a clarification that it was not permitted for individuals to file requests. The organizers then decided to file another application under the name of an organization, which the Ministry agreed to consider (Agence France Presse, 29 March 2001). This application was accepted and the 'Save JBJ Rally' was finally held in late April 2001, under the auspices of local non-governmental organization Think Centre ('Jeyaretnam targets next election', 3 May 2001). 
Other kinds of permits were also required for the selling of Jeyaretnam's books and for displaying banners at the rally. The organizers had to apply for a permit at the Hawkers' Department to sell books, t-shirts and stickers (Think Centre, 19 April 2001), and eventually received an exemption for it. Another layer of bureaucracy involved getting permission for some banners to be approved for use at the stadium that was the venue of the rally. This was granted after the Singapore Sports Council - which managed the stadiums - endorsed the banners in accordance with the rules set by the Building and Construction Authority (Think Centre, 22 April 2001).

The changes in the Act did not result in any significant increase in support or facilitation of free speech for opposition parties. In August 2001, the Singapore Democrat Party applied for a permit to hold an outdoors National Day rally. It was granted after some delay, but the police stipulated that the party would need to hire a specified number of security guards at its own cost (ST, 15 August 2001). Another example was when Chee and SDP official Gandhi Ambalam were arrested after they tried to hold a May Day rally in front of the presidential palace in 2002 without the necessary permit from the PEMA. During the trial, a lawyer for the defence argued that the 'crowd' which was presented by the prosecution as a potential law-and-order problem was actually made up of journalists (Agence France Presse, 1 October 2002). However, they were found guilty and jailed in October 2002. Chee was jailed after refusing to pay fines totalling $S \$ 4,500$ : this was broken down as $\$ \$ 4,000$ for breaching the Act, and $\$ \$ 500$ for 'wilful trespass'. Ambalam was fined $\$ \$ 3,000$ for the lack of a permit and for 'disorderly behaviour'. The authorities had denied the SDP permission to hold a rally, but Chee and Ambalam tried to carry on with it and both were arrested. Chee was jailed for five weeks after refusing to pay the fines, and Ambalam served one night in prison before settling his fines the next day (South China Morning Post, 10 November 2002).

In 2002, Chee Soon Juan, secretary-general of the Singapore Democratic Party, spoke at the Speakers' Corner urging Singaporeans 'of different races and religions to tolerate each other's views and boost religious harmony and social cohesion'. Even though he maintained that he was not breaching the 'no religion and disharmony' rules (ST, 27 July 2002), he also spoke on the 'tudung issue', a controversy regarding the barring of three Muslim girls from state schools after they had worn headscarves - or 'tudungs' - to class. Chee, in his defence, argued that his speech was neither religious nor aimed to 'cause enmity, hatred, 
hostility and ill-will about any racial or religious group', and that he was within his right to speak at the Speakers' Corner and therefore did not require a separate public entertainment licence (Chee 2002). Nevertheless, he was charged with breaking the law of not applying for a public entertainment licence and was fined $\$ \$ 3,000$, as the judge ruled that Chee's speech 'clearly constituted public entertainment as defined in the Act' (Reuters, 30 July 2002).

So when Singapore's third prime minister, Lee Hsien Loong, announced during a National Day Rally speech a partial relaxation of the rules on the expression of political views in 2004, it was greeted with limited enthusiasm. Lee in his speech announced that Singaporeans would no longer need police approval to speak at indoor gatherings (Agence France Presse, 22 August 2004). Some days later, the Singapore police clarified that indoor talks would, from 1 September 2004, no longer require licences provided they were held in an enclosed space 'which is not within the hearing or view of any person who is not attending or participating' in the meeting. They further stipulated that only Singapore citizens were allowed to organize and address such gatherings; and a Public Entertainment and Meeting licence would still be required under the Act if a foreign speaker were involved. In addition, the police said that the lecturers and speakers must not deal with any matter 'which relates, directly or indirectly, to any religious belief or to religion generally' or 'which may cause feelings of enmity, hatred, ill-will or hostility between different racial or religious groups in Singapore' (Agence France Presse, 27 August 2004).

Hence, it was no surprise that opposition MP and Workers' Party secretary-general Low Thia Khiang criticized these moves as simply 'opening up within a confined space'; and said that such measures would have a limited impact on the rest of society. Low said if the government was serious about encouraging diverse views, 'it should have free speech venues in all HDB neighbourhood parks' and that 'a mature society can and should allow people to discuss such issues and the audience should be able to make judgments for themselves'. He added that this relaxation was being promulgated as 'real change' to convince Singaporeans and overseas critics that Singapore was now an open society in which democratic rights would be protected by the current prime minister (ST, 25 August 2004).

Long-time constitutional expert and academic Kevin Tan had this to say about the amendment: 
I think the recent announcement of waiver of permits for indoor meetings goes a long way to reduce the impact of the Public Entertainments and Meetings Act (PEMA). However, the PEMA still gives the police too much power to decide how the right to free speech and assembly are to be exercised in Singapore. They have much discretion to decide whether or not to grant a permit and to designate where the meeting or speech will take place. ${ }^{6}$

The waiver of permits does reduce a layer of administration for political parties, but the fact that this waiver applies only to indoor venues means that these generally remain small or else there is a high cost of rental involved for larger indoor venues. Some political parties such as the Workers' Party, which held a public consultation exercise with its members as speakers in March 2005, did so without any consideration to changes in the public-speaking guidelines. But many political commentators remain sceptical as to how far this will affect the freedom of expression of opposition politicians and political parties so long as permits for outdoor activities continue to be denied by the police (see Table 2 for a listing of applications of outdoor activities that were denied).

\section{TABLE 2: Denial of Permits}

\begin{tabular}{|l|l|l|l|}
\hline Name & Party & $\begin{array}{l}\text { Date of Pro- } \\
\text { posed Event }\end{array}$ & Activity \\
\hline J. B. Jeyaretnam & WP & 9 January 1982 & Rally in Anson \\
\hline $\begin{array}{l}\text { Low Thia Khi- } \\
\text { ang }\end{array}$ & WP & 1993 & $\begin{array}{l}\text { Democracy Day dinner in open } \\
\text { space (i.e. outdoors) }\end{array}$ \\
\hline Chee Soon Juan & SDP & $\begin{array}{l}12 \text { \& } 15 \text { August } \\
1999\end{array}$ & $\begin{array}{l}\text { Outdoor political rallies to speak } \\
\text { on 'the need for political open- } \\
\text { ness in Singapore' }\end{array}$ \\
\hline Chiam See Tong & SPP & $\begin{array}{l}\text { 20 November } \\
1999\end{array}$ & $\begin{array}{l}\text { Political speech at party anni- } \\
\text { versary dinner }\end{array}$ \\
\hline J. B. Jeyaretnam & $\begin{array}{l}\text { Former } \\
\text { secretary- } \\
\text { general of } \\
\text { the WP }\end{array}$ & 5 January 2003 & $\begin{array}{l}\text { Protest march against goods and } \\
\text { services tax hike }\end{array}$ \\
\hline J. B. Jeyaretnam & $\begin{array}{l}\text { Former } \\
\text { secretary- } \\
\text { general of } \\
\text { the WP }\end{array}$ & 17 April 2005 & Protest march against casino \\
\hline
\end{tabular}

Sources: Agence France Presse (1999) 'Singapore Bars Outspoken Opposition Leader Chee from Holding Rallies', 5 August; Agence France Presse (2002) 'Jeyaretnam Slams Police Refusal to Allow Protest March', 30 December; Lydgate, Chris (2003) Lee's Law: How Singapore Crushes Dissent; Scribe Publications, Australia; Reuters (2005) 'Singapore Rejects Bid for Casino Protest March', 31 March; The West Australian (1999) 'Police Stop Party Talk', 22 November. 
This scepticism was borne out when the Open Singapore Center ${ }^{7}$ organized a public meeting on the subject of the death penalty and ran into several problems. First, their foreign speaker, Amnesty International representative Tim Parritt, was declined a professional visitor's pass by the Immigration and Checkpoint Authority. This meant that he was effectively banned from speaking at the meeting (Singapore Democratic Party, 9 May 2005a). Second, during the meeting, a police officer in plain clothes identified himself as a policeman and asked for the identity and nationality of the moderator. During the forum two uniformed policeman even entered the room ${ }^{8}$. Quite clearly the waiver for a licence for indoor activities did not mean that the police would cease to monitor such activities to check for infringements. The police presence seems to be guided by the belief that such activities may infringe other laws. So in spite of the 'relaxation', the police continue to monitor and intervene in public-speech activities in order to exercise control, thereby diluting these so-called measures of liberalization.

\section{Election Rallies: Defamation Laws and Other Regulations}

Although permits have frequently been denied for outdoor political meetings, even under the revised PEMA when the police cite law-andorder issues as pretext, the police do issue special guidelines during election time. According to these guidelines, outdoor election rallies or meetings for mass direct communication can be held from Nomination Day until the eve of Polling Day. They can be held from 7 am until 10 $\mathrm{pm}$. Lunch-time rallies can only be held between $11.30 \mathrm{am}$ and $2.30 \mathrm{pm}$. In order to hold an election rally or meeting, a permit still needs to be obtained. A candidate or an authorized election agent must apply personally in writing for the permit not later than 2.30 pm one day before the rally. Written permission for the use of rally sites is also needed from the respective authorities. Such rallies can only be held in sites approved by the police. Election meetings can also take place indoors but these too require a police permit and the permission of the owner of the premises (ST, 20 December 1996).

But even this limited provision during elections is not without its problems. The space allowed political parties during election periods has been affected by the use of defamation laws to prosecute political opponents, by both the PAP government and individual PAP politicians. ${ }^{9}$ The legislation governing defamation laws comprises the Defamation 
Act $(1957,1997)$, which deals with libel, slander and falsehoods. Civil libel or slander suits - or the threat of them - have often been used by government leaders to intimidate opposition leaders and political opponents. The Penal Code also provides for criminal defamation offences. Even the Internal Security Act can be used against someone who speaks in a manner likely to incite violence. Other provisions include those that rule certain subject matters in speeches as being in contempt of court.

Defamation suits have been used against opposition politicians during election rallies, notably in the cases against J. B. Jeyaretnam, Tang Liang Hong ${ }^{10}$ and Chee Soon Juan for allegedly defaming PAP figures in speeches made during election time. The peculiar nature of these suits has been highlighted in reports submitted to organizations like Lawyers' Rights Watch Canada. These reports have expressed concern that 'defamation proceedings against Mr. Jeyaretnam and other government critics have impaired the right of Singaporeans to fully engage in professions that carry with them the duty or responsibility to, when necessary, be critical of government'. One of the observers believed that 'there has to be some leeway granted in law to political candidates in elections'. This is called the 'defence of qualified privilege', which permits political candidates 'to raise issues of concern to the public' (Davidson and Rubin 2001). This means that an opposition politician should be entitled to raise issues of concern and that there needs to be some response from the government.

However, in Singapore there is no such defence, and the courts 'will presume that the speaker intended to assert the truth of the matter being raised', and prosecute accordingly. Speakers thus run the risk of being sued for defamation, especially during election time in the cut and thrust of political speeches. The defence of qualified privilege is precluded in Section 14 of the Defamation Act, which is designed to severely restrict the freedom to discuss 'questions in issue'. Conversely, this section of the Act focuses on protecting a plaintiff's reputation rather than protecting fair comments by politicians in any political discussions or debate (upon which an election usually depends). In this area, the defamation law in Singapore sets itself against the laws in other Commonwealth countries (Davidson and Rubin 2001) and makes a 'radical departure from its common law roots' (Bryan and Rubin 2004: 1). However, in Singapore, it is the case law made by judges that shapes the parameters of free speech, not the Act itself. This is very different from the laws of the PEMA, which are very restrictive but at least have the benefit of being quite clear because they are in statutory form. 
PAP government leaders thus use court proceedings and defamation suits against political opponents and critics. Such suits that are often decided in favour of PAP plaintiffs have created the perception that the ruling party uses the judicial system for political purposes. Costly judgments in libel suits do lead to bankruptcy, and under the law, bankrupt persons are ineligible to sit in Parliament. This has been the fate of the first post-independence opposition MP J. B. Jeyaretnam; other prominent cases include Tang Liang Hong and Chee Soon Juan. It has had a stifling effect on the full expression of political opinion and has disadvantaged the political opposition.

One of the early cases of defamation was brought against both an opposition-connected newspaper and an opposition politician in 1973. The Chern Sien Pao was successfully sued by then-prime minister Lee Kuan Yew for publishing 'slanderous remarks' made by Barisan Sosialis electoral candidate Harban Singh. Singh himself was jailed for one month for 'criminal defamation of the prime minister' (Seow 1998: 130).

Three years later in 1976, Ho Juan Thai of the Workers' Party (WP) was accused by the PAP of making speeches 'inciting the Chinese-speaking to violence on the language issue' during the general election. A warrant for his arrest was issued under the Internal Security Act, and Ho fled to London as soon as the result of the poll was announced. After the elections in that same year, the then-secretary general of the WP was sued for defamation by then-prime minister Lee Kuan Yew for saying during an election rally 'that a bank of which his [Lee's] brother was a director had been given a banking licence when other companies applying for banking licences had not been able to get their licences'. Jeyaretnam was found guilty in the High Court, and ordered to pay damages of $S \$ 130,000$, with total costs amounting to $\$ \$ 500,000$ (Low et al. 1997).

In the 1980s, an election rally during the 1988 general election was the venue at which Jeyaretnam questioned the PAP government's investigation of the suicide of the minister for national development, Teh Cheang Wan. He 'also asked whether the prime minister had replied to a letter written to him by Teh'. Lee Kuan Yew commenced a case against Jeyaretnam for slander, because 'his words at the election rally were understood to mean that Lee had aided and abetted Teh Cheang Wan to commit suicide, which was a criminal offence'. Again, Jeyaretnam was found guilty and ordered to pay Lee damages of $\$ \$ 260,000$ together with interest on the amount and costs (Low et al. 1997).

The 1990s began with more charges against Workers' Party electoral candidates. Gopalan Nair was charged with contempt of court 'for mak- 
ing a speech at an election rally in which he was alleged to have cast aspersions on the system of promotion of judges in the Subordinate Courts'. He was found guilty and fined $S \$ 8,000$ by a judge of the High Court, and later ordered to pay $S \$ 13,000$ to the government for legal costs.

On the few occasions where permits were issued for a rally in an enclosed space (e.g. a football stadium), WP member Wee Han Kim apologized publicly to the then-senior minister Lee Kuan Yew and his son, then-first deputy prime minister Lee Hsien Loong, for making a speech at a party Labour Day rally 'implying that the latter had gained his pre-eminent public office not on his own merits but due to the nepotistic influence of his father' in mid-1992. Before any writ could be issued, Wee agreed to pay damages for defamation of $\$ \$ 100,000$ to each of the Lees, plus legal costs and other charges amounting to approximately S\$223,000 (Low et al. 1997).

In 1997, Tang Liang Hong, formerly of the Workers' Party, was hit by 13 libel suits from PAP ministers and MPs, including the then-senior minister and then-prime minister, when he called them liars after they had labelled him an 'anti-Christian, Chinese chauvinist and a dangerous man'. Tang left Singapore for Johor, Malaysia after receiving death threats. He also faced charges from the Inland Revenue Authority for evading taxes. After Tang left, the plaintiffs 'obtained an injunction against Tang to restrain him from disposing of his assets and requiring him to disclose the whereabouts of all his assets'. The plaintiffs obtained default judgments against Tang in all their suits after Tang 'failed to file an affidavit disclosing his assets'. A judge at the High Court assessed Tang's incurred damages at $\$ \$ 8,075,000$ (Low et al. 1997).

Related to this case was that of J. B. Jeyaretnam in that same year, who faced nine defamation suits by 11 PAP ministers and MPs 'for saying at an election rally that Tang Liang Hong had just handed him two police reports made by Tang Liang Hong 'against Goh Chok Tong and his people'. The judge at the trial found that Jeyaretnam's words were defamatory 'but of a much lesser meaning than that claimed by Goh'. The judge awarded Goh 10 per cent of the $\$ \$ 200,000$ damages claimed by him, and also ordered Jeyaretnam to pay 60 per cent of Goh's costs (Low et al. 1997). Jeyaretnam in April 2002 formally apologized to thensenior minister Lee Kuan Yew and other PAP members for the remarks made during the 1997 campaign. In exchange for the apology, the men dropped defamation lawsuits against Jeyaretnam and agreed to forgo damages (Agence France Presse, 2 April 2002).

This offer was though of no consequence, as Jeyaretnam had already 
been declared bankrupt in 2001 and had lost his seat in Parliament. He had lost a final appeal against the bankruptcy order, which stemmed from a lawsuit filed against him by PAP officials who claimed that he had defamed them in the Workers' Party newspaper the Hammer in 1995, when Jeyaretnam was its editor. An article there had criticized the organizers of a campaign promoting the use of the Tamil language (South China Morning Post, 24 July 2001). Accordance to Singapore law, bankruptcy disqualifies a person from holding public office.

The latest of the election-related defamation suits took place at the end of 2001. Then-senior minister Lee Kuan Yew and then-prime min-

\section{TABLE 3: Defamation and Other Criminal Offences during Election Campaigns}

\begin{tabular}{|c|c|c|c|c|}
\hline Name & Party & Date & Charge & Nature of Penalty \\
\hline Harban Singh & $\begin{array}{l}\text { Barisan } \\
\text { Sosialis }\end{array}$ & 1973 & $\begin{array}{l}\text { Criminal defamation of the prime } \\
\text { minister }\end{array}$ & Jail - 1 month \\
\hline Ho Juan Thai & $\begin{array}{l}\text { Workers' } \\
\text { Party }\end{array}$ & 1976 & $\begin{array}{l}\text { Accused by the PAP of making } \\
\text { speeches inciting the Chinese- } \\
\text { speaking to violence on language } \\
\text { issue (during elections) }\end{array}$ & $\begin{array}{l}\text { Warrant for arrest issued under the Internal } \\
\text { Security Act. Ho fled to London as soon as the } \\
\text { result of the polls was announced, and is still } \\
\text { residing in the United Kingdom. }\end{array}$ \\
\hline $\begin{array}{l}\text { J. B. Jeyaret- } \\
\text { nam }\end{array}$ & $\begin{array}{l}\text { Workers' } \\
\text { Party }\end{array}$ & 1976 & $\begin{array}{l}\text { Sued for defamation by Lee Kuan } \\
\text { Yew for things said at general } \\
\text { election rally }\end{array}$ & Damages of $\mathrm{S} \$ 130,000$ awarded to Lee. \\
\hline $\begin{array}{l}\text { J. B. Jeyaret- } \\
\text { nam }\end{array}$ & $\begin{array}{l}\text { Workers' } \\
\text { Party }\end{array}$ & 1988 & $\begin{array}{l}\text { Sued for defamation by Lee Kuan } \\
\text { Yew for things said at general } \\
\text { election rally }\end{array}$ & $\begin{array}{l}\text { Damages of } \$ \$ 260,000 \text { awarded to Lee, plus } \\
\text { interest and costs }\end{array}$ \\
\hline Gopalan Nair & $\begin{array}{l}\text { Workers' } \\
\text { Party }\end{array}$ & 1991 & $\begin{array}{l}\text { Contempt of court for casting as- } \\
\text { persions on system of promotion of } \\
\text { judges in speech at election rally }\end{array}$ & $\begin{array}{l}\text { Fined } \$ \$ 8,000 \text { and ordered to pay } S \$ 13,000 \text { to } \\
\text { government for legal costs }\end{array}$ \\
\hline Wee Han Kim & $\begin{array}{l}\text { Workers' } \\
\text { Party }\end{array}$ & 1992 & $\begin{array}{l}\text { Accused of defaming Lee and Lee } \\
\text { at Labour Day Rally }\end{array}$ & $\begin{array}{l}\text { Damages paid to plaintiffs plus legal costs and } \\
\text { advertisement charges totalling } S \$ 223,000 \text {. }\end{array}$ \\
\hline $\begin{array}{l}\text { J. B. Jeyaret- } \\
\text { nam }\end{array}$ & $\begin{array}{l}\text { Workers' } \\
\text { Party }\end{array}$ & 1995 & $\begin{array}{l}\text { Accused of defaming PAP officials } \\
\text { in party newsletter article when he } \\
\text { was the editor }\end{array}$ & $\begin{array}{l}\text { Damages of } \$ \$ 235,000 \text { awarded to plaintiffs. } \\
\text { Declared bankrupt and barred from Parlia- } \\
\text { ment after failing to pay the final instalment. }\end{array}$ \\
\hline $\begin{array}{l}\text { Tang Liang } \\
\text { Hong }\end{array}$ & $\begin{array}{l}\text { Workers' } \\
\text { Party }\end{array}$ & \begin{tabular}{|l} 
Jan. \\
1997
\end{tabular} & $\begin{array}{l}\text { Civil defamation suit - accused of } \\
\text { defaming PAP members through } \\
\text { police reports }\end{array}$ & $\begin{array}{l}\mathrm{S} \$ 8,000,000 \text { in damages awarded to PAP } \\
\text { plaintiffs. }\end{array}$ \\
\hline $\begin{array}{l}\text { J. B. Jeyaret- } \\
\text { nam }\end{array}$ & $\begin{array}{l}\text { Workers' } \\
\text { Party }\end{array}$ & $\begin{array}{l}\text { Jan. } \\
1997\end{array}$ & $\begin{array}{l}\text { Accused of defaming Goh Chok } \\
\text { Tong at election rally }\end{array}$ & $\begin{array}{l}\text { Civil defamation suit by Goh and } 10 \text { other } \\
\text { PAP politicians were dropped after Jeyaret- } \\
\text { nam apologized. }\end{array}$ \\
\hline $\begin{array}{l}\text { Chee Soon } \\
\text { Juan }\end{array}$ & $\begin{array}{l}\text { Singapore } \\
\text { Democrat } \\
\text { Party }\end{array}$ & $\begin{array}{l}\text { Nov. } \\
2001\end{array}$ & $\begin{array}{l}\text { Accused of defaming then- PM } \\
\text { Goh and then-SM Lee during } 2001 \\
\text { election campaign }\end{array}$ & $\begin{array}{l}\text { Ordered by the High Court to pay a total of } \\
S \$ 500,000 \text { in damages to Goh and Lee. }\end{array}$ \\
\hline
\end{tabular}

Sources::Agence France Presse (2001) 'Opposition MP Files Appeal against Bankruptcy Order'. 22 February; Agence France Presse (2002) 'Jeyaretnam Says Sorry, Defamation Charges Dropped'. 2 April; Low Thia Khiang, Huang Seow Kwang, K. Mariappane and Rahim Osman (1997) The Workers' Party 40 th Anniversary Magazine; The Workers' Party, Singapore; Mutalib, Hussin (2003) Parties and Politics: A Study of Opposition Parties and the PAP in Singapore, Eastern Universities Press, Singapore; ST (2005) 'SDP Chief Could be Declared Bankrupt'. 17 March; Seow, Francis T. (1994) To Catch a Tartar: A Dissident in Lee Kuan Yew's Prison; New Haven, Conn.: Yale University Southeast Asian Studies. 
ister Goh Chok Tong sued Chee Soon Juan, leader of the Singapore Democratic Party (SDP), for defamation based upon comments Chee had made during a campaign stop in the November 2001 general election. Chee had allegedly accused them of 'misleading Parliament over an alleged S\$17 million (US\$10 million) loan to former Indonesian President Suharto' (Agence France Presse, 6 September 2004; ST, 17 March 2005). In March 2005 it was reported that SDP chief Chee Soon Juan 'failed to meet a demand by lawyers acting for Mr Goh Chok Tong and $\mathrm{Mr}$ Lee Kuan Yew that he pay $\$ \$ 500,000$ in damages awarded to them by the High Court'. The court had ruled in January that Chee had to pay S\$300,000 to Goh and $\$ \$ 200,000$ to Lee for defaming them during the 2001 election campaign (ST, 17 March 2005).

In spite of the guarantees of freedom of speech, as laid out in Article 14 of the Singapore Constitution, opposition figures have borne the brunt of the defamation charges during election rallies. Table 3 provides an overview of defamation suits brought against opposition figures by PAP officials, mainly arising from speeches made during election rallies. A pattern has emerged whereby these suits have become a tool to attack opposition leaders and candidates during election times, and the fines have been especially heavy and aimed at bankrupting them.

\section{Policing Speech in Parliament}

In the preceding sections we saw how the work of opposition politicians and parties ran into difficulties because of strict legislation surrounding public speaking. What is interesting about the Singapore case is that such restrictions in some ways also extend to speech in Parliament. Article 63 (Privileges of Parliament) of the Singapore Constitution states: 'It shall be lawful for the Legislature by law to determine and regulate the privileges, immunities or powers of Parliament.' This 'merely allows Parliament to regulate its own privileges, immunities and powers' (Tan et al. 1991).

Such privileges and procedures are recorded in the Standing Orders of the Parliament of Singapore. The Standing Orders among other things offer guidance on how debate is to be conducted in Parliament. For instance, there are clear and distinct time limits for MPs when answering questions, when addressing specific committees of parliament, and for proposing motions. In respect to replying to questions, the orders state that 'no Member shall be entitled to speak to any question in Parliament 
for more than 30 minutes, or to address a Committee of the whole Parliament for more than 15 minutes at any one time'. For motions, the 'mover of an original motion shall be entitled to not more than one hour for his opening speech and another hour for his reply' (Standing Orders of the Parliament of Singapore 2004). Overall the rules about speaking times favour a minister more than an ordinary backbencher. The time limits indicated in the current Standing Orders are sparse compared to speaking times in earlier parliaments. For instance, David Marshall spoke for six hours during a debate on constitutional proposals in 1957. In 1961, Lee Siew Choh of the Barisan Sosialis spoke for more than seven hours, lasting until almost four o'clock the following morning (Chan 2001: 239, 255).

Like the PEMA and the Defamation Act, these rules apply to all MPs of all parties. However, the requirement that at least a certain number of MPs are needed to move a motion in the current Standing Orders does impact primarily on the opposition MPs, as in the present Parliament there are only two elected opposition MPs from two different parties, and one NCMP ${ }^{11}$. When the Standing Orders are amended to either reduce the time allowed for a member to speak, or to curtail opportunities for speaking, it not only impedes the opposition's ability to communicate their constituency's concerns, it also erodes their ability to be effective. Parliament is essentially a numbers game. With few opposition politicians from different parties, the total time allocated to them will be correspondingly reduced when time is reduced. The incumbent can still spread the time around, especially when they have so many members in the Chamber. Further, apart from the rules contained in the Standing Orders, how the speaker applies these rules are also important. ${ }^{12}$

One key provision within the Standing Orders of the Parliament of Singapore relates to the powers and operations of the Committee of Privileges. The Committee consists of eight MPs who conduct hearings into cases of alleged parliamentary misconduct by other MPs (Standing Orders of Parliament of Singapore 2004). The Committee is composed of mostly MPs from the ruling PAP, with usually just one opposition MP. There has been at least one instance of the use of this committee in the history of the Singapore Parliament, namely when it was used against MP David Marshall in 1962. Like Jeyaretnam, Marshall was a criminal defence lawyer who wanted to raise in Parliament an issue that was related to one of his cases. The Committee of Privileges presided over this and concluded that because Marshall was a lawyer involved in the case, he was not entitled to raise it in Parliament, even in general terms (Lydgate 2003: 109). 
When J. B. Jeyaretnam was elected in the Anson by-election, this tool was more visibly deployed as a form of disciplinary action against the opposition politician. He was referred to the Committee the first time in 1982, and received no punishment after the Speaker accepted his apology (Lydgate 2003: 110-14). The second time was in 1986, when the Speaker of the House again referred him to the Committee of Privileges for disciplinary action (Lydgate 2003: 160). Jeyaretnam was accused of making an unsubstantiated statement in Parliament concerning a member of the public's wrongful arrest, and for 'failing to declare his pecuniary interest in a matter raised by him in Parliament' (Low et al. 1997).

In late 1986, two weeks before Jeyaretnam's hearing by the Committee, Parliament had rushed through a special amendment increasing the punishment of errant MPs. Dishonourable conduct, abuse of privilege and contempt were now punishable by a fine of up to $\$ \$ 50,000$, from a previous maximum of $S \$ 1,000$. Members could also be stripped of their privileges and be liable to face civil lawsuits. The new penalties were not retroactive, but they would apply to anything Jeyaretnam said during the hearing (Lydgate 2003: 169-70). Although MPs were usually protected by law from defamation in Parliament, in practice, however, the nature of his questioning during the Committee hearing indicated that this protection was being retroactively stripped away (Lydgate 2003: 172). In other words, what Jeyaretnam said before the amendment would not be taken into account, but what he was to say henceforth was to be governed by this new ruling. By December that year Jeyaretnam had been fined a few more times after being referred to the Committee of Privileges for more offences related to alleged misconduct regarding parliamentary issues. These fines added up to a substantial amount (Low et al. 1997).

A second such incident occurred nine years later in November 1996, when the committee found four members of the Singapore Democratic Party (SDP) 'guilty of contempt of Parliament'. The four, including the SDP secretary-general Chee Soon Juan, were 'found guilty of perjury, wilfully giving false answers, prevaricating and misconducting themselves as witnesses' over data on healthcare (ST, 12 December 1996). Earlier that year, the SDP had stated in a report that the government's share of healthcare spending had dropped from 27 per cent in 1989 to 5 per cent in 1990. They reiterated this claim during a Select Committee hearing in July 1996, but later said this was a typing error and that the number should be 25 per cent instead of 5 per cent. Charges were filed by the health minister against four members of the SDP, and they were summoned to appear before the Committee of Privileges (ST, 26 October 1996). 
The four were SDP secretary-general Chee Soon Juan, Wong Hong Toy, S. Kunalen and Kwan Yue Keng. Charges against them included 'perjury, prevarication, misconduct and wilfully giving false evidence' before the Health Select Committee convened earlier that year. During the 12-hour session with the Committee of Privileges, Chee said that 'he was only human and so had made errors in a report the party had presented to the Select Committee' (ST, 1 November 1996). They were variously fined between $\$ \$ 5,000$ and $\$ \$ 25,000$ each, but as Parliament was not a court of law, 'the fines do not bar the SDP members from contesting in the coming General Election [of 1997]' (ST, 23 November 1996). Low Thia Khiang, the only opposition MP in the Committee of Privileges, tried unsuccessfully to reduce the fines recommended for the SDP members (ST, 24 November 1996).

This shows that even if an opposition politician wins a seat in Parliament or is involved in any proceedings initiated under the authority of Parliament, he or she runs the risk of breaching 'privileges' and could suffer punitive actions.

\section{The Impact of Free Speech Restrictions on Opposition Parties}

The presence of several layers of rules that govern free speech influences the ways in which free speech is perceived and executed by opposition parties in Singapore. It also affects how free-speech activities are deployed, or whether they are deployed in the first place.

For instance, it is not uncommon to hear members of opposition parties who insist that there is actually free speech in Singapore as long as one seeks to exercise free-speech activities within the framework of current rules, although they acknowledge that there is a certain layer of administration that exists for obtaining licences and permits. With announcements made by Lee Hsien Loong in 2004, at least one layer of administration has been removed. However there is agreement that outdoor political speeches are not free, nor are the rules fair.

But such interpretations also lead to other issues regarding the type or quality of opposition politicians. Some opposition politicians are viewed as moderate, e.g. Chiam See Tong and Low Thia Khiang, whose existence in the parliamentary system is often cited by the ruling party to underscore the legitimacy of the political system under its rule (ST, 12 October 2005; see also conclusion). On the other hand, opposition

politicians such J. B. Jeyaretnam or Chee Soon Juan are often berated 
because they are more robust in their criticism of the ruling PAP, especially when it comes to free speech.

Another factor that affects free speech is the impact of defamation laws. Some writers have observed that defamation laws create a climate of fear, which frequently results in self-censorship of speech (Lydgate 2003; Davidson and Rubin 2001). This forces opposition politicians to be ultra-careful with regard to what they say in public. At the party level, this slows down decision-making about engaging in public-free speech activities such as rallies and forums ${ }^{13}$. It may even limit the number of free-speech activities that opposition parties are willing to undertake.

On the other hand, some argue that the indirect consequences of such defamation laws may be positive: that they may improve opposition communications and make opposition politicians more responsible for what they say. ${ }^{14}$. For instance, more strenuous efforts will be made to verify facts and figures before making statements on political matters. However, there remains the concern that not only does the Defamation Act restrict free speech, for example through self-censorship, but that even if opposition politicians exercise caution, they may infringe the law through some obscure technicality.

In real terms, the political value of free speech for opposition parties is limited. Many commentators argue that how Singaporeans view the opposition depends on how the media reports on the opposition. ${ }^{15}$ Free-speech activities such as forums and rallies, and the content of what is said during those activities, can only have limited impact if the media, especially the local media, choose not to report it. Thus, the wider dissemination of content is kept in check, either by the non-reportage or sometimes negative reporting of such activities by the media. The mainstream local media, by nature largely pro-PAP, sometimes ignore and even distort opposition parties' viewpoints. Although there has been some dissemination of such information by international NGOs and Media Watch organizations, their reach has been limited given the fact that such international NGOs do not have an effective local partner (Gomez 2005).

\section{Civil Disobedience as an Option}

The various obstructions to freedom of expression, electoral fairness and the impact of other laws have led opposition politicians like Chee Soon Juan to advocate the concept of non-violent civil disobedience as being the only avenue left, given that the parliamentary process is not viable because of the PAP's dominance. Chee has said that he 'sees non-violent 
civil disobedience and protest as a viable long-term strategy to change the present system in Singapore' (ST, 10 July 2005).

When there are criticisms of Singapore's laws from opposition politicians like Chee, spokespersons from the PAP government have a number of stock responses. One example goes like this: 'If any Singaporean disagrees with our tough laws ... the proper and democratic way to proceed is to contest and win an election, and press to change the law in Parliament' (ST, 27 November 2005). Alternatively, they will point out that there are 'established avenues for reviewing and changing' unjust laws, and that other opposition MPs (such as Chiam See Tong and Low Thia Khiang) did not have to resort to civil disobedience in order to get themselves elected (ST, 12 October 2005).

However, the laws governing Singapore's electoral process are themselves biased in favour of the ruling PAP, and are aimed at making opposition parties 'ineffectual and unable to challenge the PAP' (Chee 2005: 45) by creating a playing field that is far from level. It is these uncertainties and a sense that nothing will change that prompted opposition politician Chee Soon Juan to cite civil disobedience as the only option left to change the laws. Chee Soon Juan's acts of civil disobedience since 1998 are based on this belief and have sought to highlight how these laws disadvantage and are selectively used against the opposition (Singapore Democratic Party, 28 June 2005b).

Chee has officially mounted a civil disobedience campaign, beginning with flouting public speaking rules, refusing to pay fines and going to prison (ST, 10 October 2005). His actions have drawn attention to laws like licensing rules for public events, and were instrumental in leading to some limited liberalization by the government, for example in establishing a Speakers' Corner and a relaxation of the licensing rules for indoor talks (George 2005: 23).

Even with limited liberalization, there are other levels of monitoring and controls that prevent full implementation of these laws. An incident illustrating this took place on 9 July 2005, during the launch of Chee Soon Juan's new book on civil disobedience The Power of Courage at a local hotel. Plain-clothes policemen seized a video disc which had been playing a film in the background while Chee was autographing his book. The police officers stated that they were seizing the disc because it did not have a certificate for public exhibition, an offence under the Films Act. The police officers were caught on film recording the entire book launch with a video camera, and the incident was reported on the Singapore Democratic Party's website (Singapore Democratic Party, 
9 July 2005c). This shows that in spite of official liberalization of the laws, in practice the activities of certain opposition politicians are still being closely watched and have come up against the repressive tools of authority. This means that freedom of expression requires considerable freedom of movement, assembly and association in order to render political expression meaningful. This is certainly not the case in Singapore under the ruling PAP government.

Chee's promotion of civil disobedience activities using methods of non-violence as an opposition strategy (ST, 10 October 2005) is an attempt to effect change in Singapore. However, the PAP government has begun to counter the strategy by emphasizing that political change must be brought about through 'constitutional and lawful means', and that 'Singaporeans are free to express themselves politically within the law' (ST, 17 September 2005). It is too early to tell if civil disobedience can make a dent in Singapore's free-speech laws. But the pressure from such civil disobedience acts has certainly been felt by the Singapore political system.

\section{Conclusion}

The nature of restrictions surrounding free speech in Singapore serves to keep opposition parties weak since they are not able to robustly challenge the ruling party. This keeps competition between political parties at a very low level, with the opposition being unable to change the present rules and regulations. This situation relegates Singaporean democracy to an existence in name, but not in substance.

James Gomez is a PhD Candidate at the Monash Asia Institute, Monash University, Australia.

\section{NOTES}

1 The Public Entertainment Licensing Unit (PELU), a sub-unit of the Singapore Police Force issues and regulates permits for public entertainment (ST, 18 November 2000).

2 In 1988 the town councils were established and took over some of the roles from the public utility services.

3 Email response from Steve Chia, Non-Constituency MP, National Solidarity Party, 7 June 2005.

4 Email response from Yaw Shin Leong, former executive committee member, Workers' Party, and former Hougang town councillor, 7 June 2005.

5 The Think Centre was founded in 1999 as a sole proprietorship which organized 
events and published books on topics of politics and human rights. In 2001 it registered as a society and continued to organize activities around human rights themes.

6 Email response from Kevin Tan, Singapore constitutional law expert and academic, 20 May 2005.

7 A civil society organization co-founded by opposition figures J. B. Jeyaretnam and Chee Soon Juan.

8 Interview with Chee Soon Juan, secretary-general, Singapore Democratic Party on 18 April 2005 in Singapore.

9 The use of defamation is not restricted to speech during election rallies. Defamation laws have been used against opposition politicians during non-election-related activities as well as against content contained in party publications.

10 Tang Liang Hong was a Workers' Party candidate for the Cheng San GRC during the 1997 general elections. After the elections, he was sued for defamation by the then prime minister Goh Chok Tong, then senior minister Lee Kuan Yew, and nine other current or former MPs. Most of the lawsuits arose from responses Tang had made to the PAP leaders' claim, that he was an 'anti-Christian, anti-English-educated, Chinese-language chauvinist'. Immediately after the election, Tang fled Singapore, citing death threats. In May the Singapore High Court ordered him to pay the PAP leaders $\$ \$ 8.08$ million in damages.

11 The Non-Constituency Member of Parliament (NCMP) scheme was introduced in 1984, just before that year's elections. Under this scheme, the top three opposition candidates in a general election with the highest percentage of losing votes would be allowed into Parliament. NCMPs have limited voting powers and play no role in the running of town councils. The introduction of the NCMPs was to provide for some form of opposition in Parliament, even if none was directly elected.

12 Email response from Low Thia Khiang, Workers' Party Member of Parliament, 20 May 2005.

13 Email response from Melvin Tan, Workers' Party Central Executive Committee member, 30 May 2005.

14 Email response from Low Thia Khiang, Workers' Party Member of Parliament, 20 May 2005.

15 Email response from Tan Chong Kee, founder of Sintercom and member of now defunct Singapore Mediawatch Community Initiative, 16 May 2005.

\section{REFERENCES}

Agence France Presse, 5 August 1999;.22 February 2001; 29 March 2001; 4 March 2002; 2 April 2002; 1 October 2002; 30 December 2002; 22 August 2004; 27 August 2004; 6 September 2004.

Chan Heng Chee 2001. A Sensation of Independence. Singapore: Times Books. International.

Da Cunha, Derek 1997. The Price of Victory: the 1997 Singapore General Election and Beyond. Singapore: Institute of Southeast Asian Studies.

Financial Times, 27 March 1999.

George, Cherian 2005. Calibrated Coercion and the Maintenance of Hegemony in Singapore. Asia Research Institute Working Paper Series no. 48, National University of Singapore, Singapore, September.

Gomez, James 2002. Internet Politics: Surveillance and Intimidation in Singapore. Bangkok: Think Centre. 
- 2005. 'International NGOs: Filling the Civil Society "Gap" in Singapore'. In Sojourn: Journal of Social Issues in Southeast Asia 20 (2) October, Special Focus on 'Democracy and Civil Society: NGO Politics in Singapore'. Singapore: Institute of Southeast Asian Studies.

Hickling, R. H. 1992. Essays in Singapore Law. Petaling Jaya: Pelanduk Publications. Josey, Alex 1972. The Singapore General Elections 1972. Singapore and Kuala Lumpur: Eastern Universities Press Sdn Bhd.

Koh, Gillian and Ooi Giok Ling 2002. 'Singapore: A Home, A Nation?' Southeast Asian Affairs 2002. Singapore: Institute of Southeast Asian Studies.

Lam Peng Er and Kevin Tan (eds) 1999. Lee's Lieutenants: Singapore's Old Guard. Singapore: Allen \& Unwin.

Lee Boon Hiok 1985. 'Singapore in 1984'. Southeast Asian Affairs 1985. Singapore: Institute of Southeast Asian Studies.

Lew Eng Fee 1989. 'Singapore in 1988'. Southeast Asian Affairs 1989. Singapore: Institute of Southeast Asian Studies.

Low T. K. et al. (eds) 1997. The Workers' Party 40 th Anniversary Magazine. Singapore: The Workers' Party.

Lydgate, Chris 2003. Lee's Law: How Singapore Crushes Dissent. Australia: Scribe Publications.

Mutalib, Hussin 1992. 'Singapore's 1991 General Elections'. Southeast Asian Affairs 1992. Singapore: Institute of Southeast Asian Studies.

- 1993. 'Singapore's December 1992 By-elections: Interpreting the Results and Signals.' Round Table (Commonwealth Journal of International Affairs) 326: 159-68.

- 2003. Parties and Politics: A Study of Opposition Parties and the PAP in Singapore. Singapore: Eastern Universities Press.

Ooi Can Seng 1998. 'Singapore'. In Wolfgang Sachsenröder and Ulrike E. Frings (eds) Political Party Systems and Democratic Development in East and Southeast Asia. Volume I: Southeast Asia. Aldershot: Ashgate Publishing: 343-402.

Reuters, 1 February 1999; 6 March 1999; 25 May 1999; 28 February 2001; 30 July 2002.

Rodan, Garry 1996. 'Elections without Representation: the Singapore Experience under the PAP'. In Robert H. Taylor (ed.), The Politics of Elections in Southeast Asia. Cambridge: Cambridge University Press; and Washington: Woodrow Wilson Center Press.

Seow, Francis T. 1998. The Media Enthralled. Boulder, Col.: Lynne Rienner Publishers Inc.

Singh, Bilveer 1992. Whither PAP's Dominance? An Analysis of Singapore's 1991 General Elections. Petaling Jaya: Pelanduk Publications.

South China Morning Post, 24 July 2001; 10 November 2002.

Straits Times, 26 October 1996; 1 November 1996; 23 November 1996; 24 November 1996; 12 December 1996; 20 December 1996; 30 January 1999; 14 November 2000;18 November 2000; 15 August 2001; 27 July 2002; 25 August 2004; 17 March 2005; 10 July 2005; 17 September 2005; 10 October 2005; 12 October 2005; 27 November 2005.

Tan, Kevin Yew Lee 1999. 'Parliament and the Making of Law in Singapore'. In Kevin Y. L. Tan (ed.), The Singapore Legal System. Singapore: Singapore University Press.

Tan, Kevin, Tiong Min Yeo and Kiat Seng Lee1991. Constitutional Law in Malaysia and Singapore. Singapore: Malayan Law Journal.

Thio Li-ann 1997. 'Choosing Representatives: Singapore Does It Her Way'. In Graham Hassall and Cheryl Saunders (eds), The People's Representatives: Electoral Systems in the Asia-Pacific Region. Australia: Allen \& Unwin.

Tremewan, Christopher 1994. The Political Economy of Social Control in Singapore. New York: St Martin's Press. 
Vasil, Raj 1993. 'Singapore 1992'. Southeast Asian Affairs 1993. Singapore: Institute of Southeast Asian Studies.

West Australian, 22 November 1999.

Woon, Walter (1990) 'Some Check is Better than No Check', ST, 29 November.

Yeo Lay Hwee 2002. 'Electoral Politics in Singapore'. In Aurel Croissant (ed.), Electoral Politics in Southeast and East Asia. Singapore: Friedrich-Ebert-Stiftung.

\section{INTERNET SOURCES}

Bryan, Kelley and Howard Rubin 2004. The Misuse of Bankruptcy Law in Singapore: An Analysis of the Matter of Re Joshua Benjamin Jeyaretnam, ex parte Indra Krishnan. Document of Lawyers' Rights Watch Canada, October 2004.

http:/ / www.lrwc.org/pub2.php?sid=41

Davidson, Gail and Howard Rubin 2001. Defamation in Singapore: Report to LRWC in the Matter of Joshua Benjamin Jeyaretnam and Two appeal in the Court of Appeal of the Republic of Singapore. Document of Lawyers' Rights Watch Canada, September 2001. http:/ / www.lrwc.org/ pub2.php?sid=18

Chee Soon Juan, 5 January 1999. http://www.singapore-window.org/sw99/90105csj.htm

Chee Soon Juan, 29 July 2002. http://www.singapore-window.org/sw02/020729sj.htm

Chia, Roderick 2005. Said Zahari and Singapore's Four Presidents: the Left's History. http://jamesgomeznews.com/article_options.php?AID=226

Constitution of the Republic of Singapore. Singapore Statues Online. http:/ / statutes.agc.gov.sg/

Defamation Act (1997). Singapore Statues Online. http://statutes.agc.gov.sg/

Freedom House (2005) Freedom in the World 2005 Country Reports, pp. 561-65. http:/ / www.freedomhouse.org/research/freeworld/2005/Paraguay-SouthKorea. pdf

'Jeyaretnam Targets Next Election' (2001) 3 May. http://www.singapore-window.org/sw01/010503af.htm

Public Entertainments and Meetings Act (2000). http://statutes.agc.gov.sg/

Singapore Democratic Party, 9 May 2005a. http://www.singaporedemocrat.org/classic/news_display.php?id=756

Singapore Democratic Party, 28 June 2005b. http://www.singaporedemocrat.org/articlenewbook.html

Singapore Democratic Party, 9 July 2005c. http:/ / singaporedemocrat.org/articlebooklaunch.html

Standing Orders of the Parliament of Singapore as amended on 19 October 2004 (2004). Parliament of Singapore. Accessed 6 May 2005. http://www.parliament.gov.sg/Publication/Htdocs/SO-merge $\% 20$ with $\% 20$ SO $\%$ 20notes.pdf

Think Centre, 26 March 2001. http:/ / www.thinkcentre.org/article.cfm?ArticleID=568

Think Centre, 19 April 2001. http:/ / www.thinkcentre.org/article.cfm?ArticleID=670

Think Centre, 22 April 2001. http:/ / www.thinkcentre.org/article.cfm?ArticleID=682 